\title{
Sistem Pendukung Keputusan Penentu Bidang Keahlian Mahasiswa Program Studi Informatika Universitas Tanjungpura dengan Metode ELECTRE
}

\author{
Faz Faidhani $^{\# 1}$, Tursina ${ }^{\# 2}$, Anggi Srimurdianti Sukamto ${ }^{\# 3}$ \\ ${ }^{\#}$ Program Studi Informatika, Fakultas Teknik, Universitas Tanjungpura \\ Jl. Prof. Dr. H. Hadari Nawawi, Pontianak 78124 \\ ${ }^{1}$ faz.faidhaniestudent.untan.ac.id \\ 2tursina.untan.ac.id \\ ${ }^{3}$ anggidianti@gmail.com
}

\begin{abstract}
Abstrak
Kebingungan mahasiswa dalam berkonsentrasi terhadap bidang ilmu di Program Studi Informatika Universitas Tanjungpura menjadi suatu masalah bagi mahasiswa dalam menulis skripsi. Program Studi Teknik Informatika Universitas Tanjungpura memiliki kelompok keahlian yang ditujukan untuk mengarahkan judul skripsi mahasiswa sesuai ke bidangnya. Elimination Choice and Translating Reality (ELECTRE) adalah metode yang digunakan dalam penelitian ini. Metode ELECTRE adalah metode yang dapat menghasilkan keputusan dengan membandingkan alternatif secara berpasangan pada kriteria yang sama. Hasil yang didapatkan dari aplikasi ini adalah memberikan nilai rekomendasi dalam bentuk perangkingan berdasarkan hubungan antara alternatif dan kriteria yang dimasukkan. Tujuan dari penelitian ini adalah menghasilkan rekomendasi bidang keahlian untuk mahasiswa Program Studi Informatika Universitas Tanjungpura. Pengujian sistem dilakukan dengan dua cara, yaitu pengujian black box dan pengujian akurasi. Pengujian black box dilakukan untuk menguji fungsionalitas aplikasi berdasarkan input yang dimasukkan. Sedangkan pengujian akurasi adalah untuk melihat seberapa besar akurasi atau kesesuaian kelompok keahlian yang dimiliki mahasiswa dengan hasil rekomendasi sistem.
\end{abstract}

\section{Decision Support System for Determining the Areas of Expertise for Students in the Informatics Study Program at the University of Tanjungpura with the ELECTRE Method}

\begin{abstract}
Student confusion in concentrating on the field of science in the Informatics Study Program at the University of Tanjungpura is a problem for students in writing theses. Tanjungpura University Informatics Engineering Study Program has a group of expertise aimed at directing the title of the student's thesis according to their field. Elimination Choice and Translating Reality (ELECTRE) is the method used in this study. The ELECTRE method is a method that can generate decisions by comparing alternatives in pairs on the same criteria. The results obtained from this application are to provide recommendation values in the form of ranking based on the relationship between the alternatives and the entered criteria. The purpose of this research is to produce recommendations for areas of expertise for students of the Informatics Study Program at the University of Tanjungpura. System testing is carried out in two ways, namely black box testing and accuracy testing. Black box testing is carried out to test application functionality based on the input entered. While the accuracy test is to see how much accuracy or suitability of the student's expertise group with the results of the system recommendation.
\end{abstract}

Keywords: Decision Support Systems, Expertise, ELECTRE, Black Box, Accuracy. 


\section{PENDAHULUAN}

Salah satu syarat untuk menyelesaikan studi di Program Studi Informatika Universitas Tanjungpura adalah menyelesaikan tugas akhir (skripsi). Mahasiswa diwajibkan untuk menentukan judul tugas akhir terlebih dahulu, kemudian judul tersebut akan dikelompokkan ke kelompok keahlian yang diberikan oleh Program Studi Informatika Universitas Tanjungpura.

Berdasarkan masalah tersebut, maka dibuatlah sistem yang dapat menentukan bidang keahlian mahasiswa Program Studi Informatika Universitas Tanjungpura, sistem pendukung keputusan ini diharapkan dapat memberikan rekomendasi bidang keahlian bagi mahasiswa semester 5 (lima) dan mahasiswa yang sedang menulis skripsi.

Model yang digunakan dalam sistem pendukung keputusan ini adalah Multi Attribute Decision Making (MADM) dengan metode Elimination Choice of Translating Reality (ELECTRE). Metode ELECTRE dipilih karena metode ini melakukan perankingan dengan membandingkan alternative secara berpasangan. Suatu alternatif dikatakan mendominasi alternatif lain jika satu atau lebih kriterianya melebihi dan sama dengan kriteria yang tersisa, dalam hal ini alternatif yang dimaksud adalah bidang keahlian bagi mahasiswa berdasarkan kriteria yang disediakan. Dengan metode perankingan tersebut, diharapkan penilaian akan lebih tepat dan membuktikan bahwa metode ELECTRE dapat menjadi salah satu cara untuk menentukan bidang keahlian mahasiswa Program Studi Informatika Universitas Tanjungpura.

\section{LANDASAN TEORI}

\section{A. Tinjauan Pustaka}

Penelitian tentang sistem pendukung keputusan penentu bidang keahlian mahasiswa bukanlah hal yang baru dilakukan, adapun penelitian sejenis yang pernah dilakukan oleh Yumarlin MZ (2016) yang berjudul "Sistem Pendukung Keputusan Konsentrasi dan Peminatan Prodi Teknik Informatika Universitas Janabadra Yohyakarta" untuk menghasilkan sebuah rekomendasi berupa jalur peminatan mahasiswa berdasarkan nilai mata kuliah dari semester 1 sampai semester 4 [1]. Musthofa Galih Pradana (2017) dengan judul penelitian "Sistem Pendukung Keputusan Pemilihan Konsentrasi Mahasiswa Informatika Universitas Amikom Yogyakarta Menggunakan Algoritma SAW Berbasis Website menggunakan rata-rata nilai mata kuliah, minat mahasiswa dan jurusan sekolah menengah sebagai kriteria untuk merekomendasikan konsentrasi ke mahasiswa Informatika Universitas AMIKOM Yogyakarta [2]. Mulia Rahmayu, dan Rosi Kusuma Serli (2018) dengan penelitian yang berjudul Sistem Pendukung Keputusan Pemilihan Jurusan Pada SMK Putra Nusantrara Jakarta Menggunakan Metode Analytical Hierarchy Process (AHP) yang mana penelitian ini menghasilkan rekomendasi jurusan dengan menggunakan kriteria yaitu bakat, minat, kualitas jurusan, dan peluang karir [3].

Penelitian ini bertujuan untuk menghasilkan rekomendasi bidang keahlian untuk mahasiswa Program Studi Informatika Universitas Tanjungpura dengan metode Elimination Choice and Translating Reality (ELECTRE). Penelitian ini menggunakan kriteria diantaranya rata-rata nilai mata kuliah per kelompok keahlian, minat mahasiswa, dan kemampuan (hard skill) yang dimiliki mahasiswa.

\section{B. Program Studi Informatika Universitas Tanjungpura}

Program Studi Informatika merupakan salah satu program studi jenjang sarjana (S1) di lingkungan Fakultas Teknik Universitas Tanjungpura, berdiri pada tanggal 18 Mei 2014 dengan SK Dirjen DIKTI Nomor 1664/D/T/2004. Saat ini penyelenggaraan Program Studi Informatika berdasarkan SK Penyelenggaraan Nomor7325/D/T/K-N/2011 tanggal 6 Juni 2011, dan Terakreditasi B sesuai SKBANPTNomor0770/SK/BAN-PT/Akred/S/III/2017 tanggal 21 Maret 2017 [4].

Dalam penyelenggaraan pendidikan, Program Studi Informatika melaksanakan dua program studi pendidikan, yaitu program S1 Regular A dan program S1 Regular B. Kedua program ini melaksanakan kurikulum pendidikan yang sama, hanya dibedakan waktu pelaksanaan. Program Studi Informatika hingga saat ini masih menggunakan Kurikulum Kerangka Kualifikasi Nasional Indonesia (KKNI) tahun 2016. Dalam mempersiapkan lulusannya untuk terjun di masyarakat sesuai dengan standar kompetensi kerja baik nasional maupun internasional, khususnya bidang Informatika. Program Studi Informatika mempersyaratkan pembelajaran baik teori untuk penguasaan pengetahuan, praktek di laboratorium/lapangan untuk penguasaan kemampuan kerja (skills), mapun kecapakan hidup dan kemampuan manajerial.

Program Studi Informatika Universitas Tanjungpura memiliki 4 kelompok keahlian sebagai berikut:

1. Computation and Artificial Intelligent

2. Information System and Data Spatial

3. Software Engineering and Mobile Computing

4. Network and Security

\section{Sistem Pendukung Keputusan}

Sistem Pendukung Keputusan (SPK) atau Decision Support System (DSS) adalah suatu sistem informasi spesifik yang ditujukan untuk membantu manajemen dalam mengambil keputusan yang berkaitan dengan persoalan yang bersifat semi terstruktur [5]. Sistem ini memiliki fasilitas untuk menghasilkan berbagai alternatif yang secara interaktif dapat digunakan oleh pemakai. Little dalam mendefinisikan sistem pendukung keputusan (DSS) sebagai sekumpulan prosedur berbasis model untuk data pemrosesan dan penilaian guna membantu para manajer mengambil keputusan [6]. Keunikan dari SPK adalah kemampuannya dalam mengintegrasikan data dengan model-model keputusan [7]. Tujuan SPK dalam proses pengambilan keputusan adalah sebegai berikut [8]: 
1. Membantu menjawab masalah semi-terstruktur

2. Membantu manajer dalam mengambil keputusan, bukan menggantikannya.

3. Meningkatkan efektifitas pengambilan keputusan seorang manjer dari pada efisiensinya.

4. Menghemat waktu karena keputusan dapat diambil dengan cepat [9].

\section{Elimination Choice and Translating Reality (ELECTRE)}

Elimination and Choice Translating Reality (ELECTRE) adalah metode yang didasarkan pada konsep perankingan melalui perbandingan berpasangan antar alternatif pada kriteria yang sesuai [10]. Metode ELECTRE sebagai salah satu metode Multiple Attribute Decision Making (MADM) secara luas diakui memiliki performa yang baik untuk menganalisis kebijakan yang melibatkan kriteria kualitatif dan kuantitatif [11].

Metode ELECTRE sangat terkenal terutama di Eropa dan banyak digunakan dalam bidang teknik sipil dan lingkungan. Metode ELECTRE dikembangkan dengan konsep perangkingan, yaitu dengan menggunakan perbandingan berpasangan antar alternatif pada kriteria yang sesuai.

Ada beberapa langkah dalam menyelesaikan metode ELECTRE adalah sebagai berikut [12],

- Membuat matriks normalisasi

$\mathrm{Rij}=\frac{X i j}{\sqrt{\sum_{i=1}^{m} x i j^{2}}}$ dengan $\mathrm{i}=1,2 . . \mathrm{m}, \mathrm{j}=1,2, . . \mathrm{m}$

Keterangan :

Rij = matriks ternormalisasi.

$\mathrm{Xij}=$ matriks keputusan.

- Membuat matriks normalisasi terbobot

$V_{i j}=W_{j} X_{i j}$

Keterangan:

$\mathrm{Vij}=$ matriks normalisasi terbobot.

$\mathrm{Wj}=$ bobot kriteria,

$\mathrm{Xij}=$ matriks keputusan

- Menentukan indeks matriks concordance dan discordance, suatu alternatif berpasangan masuk ke himpunan concordance jika,

$\mathrm{C}_{\mathrm{k}} \geq \mathrm{C}_{\mathrm{l}}$

Dan masuk ke himpunan discordance jika,

$\mathrm{C}_{\mathrm{k}}<\mathrm{C}_{\mathrm{l}}$

- Membuat matriks concordance

$\mathrm{C}_{\mathrm{kl}}=\mathrm{W}_{1}+\mathrm{W}_{\mathrm{n}}$

- Membuat matriks discordance

$$
\mathrm{d}_{\mathrm{kl}}=\frac{\left\{\left|\max _{k l}-\max v_{l j}\right|\right\} \in d_{k l}}{\left\{\left|\max v_{k l}-\max v_{l j}\right|\right\} \forall j}
$$

- Menghitung nilai threshold

Nilai threshold concordance didapatkan dari persamaan berikut,

$$
c=\frac{\sum_{k=1}^{m} \sum_{l=1}^{m} c k l}{m(m-1)}
$$

sedangkan nilai threshold discordance didapatkan dari persamaan berikut,

$$
d=\frac{\sum_{k=1}^{m} \sum_{l=1}^{m} c k l}{m(m-1)}
$$

- Membuat matriks agregat dominan concordance dan discordance

Matriks dominan concordance dan discordance didapatkan dari persamaan,

$$
\begin{aligned}
\mathrm{F}_{\mathrm{kl}} & =1, \text { jika } \mathrm{c}_{\mathrm{kl}} \geq \mathrm{c} \\
& =0, \text { jika } \mathrm{c}_{\mathrm{kl}}<\mathrm{c} \\
\mathrm{G}_{\mathrm{kl}} & =1, \text { jika } \mathrm{d}_{\mathrm{kl}} \geq \mathrm{d} \\
& =0, \text { jika } \mathrm{d}_{\mathrm{kl}}<\mathrm{d}
\end{aligned}
$$

- Mengeliminasi alternatif less favourable $\mathrm{E}_{\mathrm{kl}}=\mathrm{F}_{\mathrm{kl}} \times \mathrm{G}_{\mathrm{kl}}$

\section{E. Hypertext Preprocessor (PHP)}

PHP (Hypertext Preprocessor) adalah bahasa server-side scripting yang menyatu dengan HTML untuk membuat halaman web yang dinamis. PHP merupakan server-side scripting maka sintaks dan perintah-perintah PHP akan dieksekusi di server kemudian hasilnya akan dikirimkan ke browser dalam format HTML. PHP termasuk dalam Open Source Product, sehingga source code PHP dapat diubah dan didistribusikan secara bebas. PHP juga bersifat lintas platform, artinya PHP dapat berjalan di banyak sistem operasi yang beredar saat ini diantaranya: Windows, Linux, Mac OS, dan Solaris [13].

\section{F. Pengujian Black Box}

Pengujian black box berfokus pada persyaratan fungsional perangkat lunak. Pengujian Black Box berusaha untuk menemukan kesalahan dalam beberapa kategori, diantraya fungsi-fungsi yang salah atau hilang, kesalahan interface, kesalahan dalam struktur data atau akses database eksternal, kesalahan performa dan kesalahan inisialisasi dan terminasi [14].

Metode pengujian black box merupakan pengujian yang dipilih berdasarkan spesifikasi masalah tanpa memperhatikan detail internal dari program, pengujian dilakukan untuk memeriksa apakah program dapat berjalan dengan benar. Pengujian black box berusaha untuk menemukan kesalahan dalam kategori sebagai berikut [15]. 


\section{G. Pengujian Akurasi}

Akurasi artinya informasi harus mencerminkan keadaan yang sebenarnya. Pengujian akurasi dilakukan oleh dua orang maupun sumber atau lebih yang berbeda, apabila pengujian tersebut menghasilkan hasil yang sama maka data tersebut dianggap akurat [16]. Melalui cara tersebut, analisis akan dilakukan untuk memberikan kesimpulan dari hasil pengujian akurasi.

\section{H. Flowchart Diagram}

Flowchart merupakan penggambaran dari langkah-langkah dan urutan prosedur suatu program. Biasanya mempermudah penyelesaian masalah yang khususnya perlu dipelajari dan dievaluasi lebih lanjut [17].

Bagan alir (flowchart) adalah bagan yang menunjukkan arus di dalam program atau prosedur sistem secara logika [18].

\section{Data Flow Diagram}

DFD (Data Flow Diagram) adalah suatu model logika data atau proses yang dibuat untuk menggambarkan darimana asal data dan kemana tujuan data yang keluar dari sistem, dimana data disimpan, proses apa yang menghasilkan data tersebutdan iteraksi antara data yang tersimpan dan proses yang dikenakan pada data tersebut [19].

DFD memiliki 3 level (tingkatan) diantaranya sebagai berikut:

1) Diagram Konteks (Context Diagram): Menggambarkan satu lingkaran besar yang dapat mewakili seluruh proses yang terdapat di dalam suatu sistem. Diagram konteks merupakan tingkatan tertinggi dalam DFD dan menggambarkan satu lingkaran besar yang dapat mewakili seluruh proses yang terdapat di dalam suatu sistem.

2) Diagram Nol: Diagram nol merupakan satu lingkaran besar yang mewakili lingkaran-lingkaran kecil yang ada di dalamnya. Diagram nol merupakan pemecahan dari diagram konteks.

3) Diagram Rinci: Diagram rinci merupakan diagram yang menguraikan proses apa yang ada di dalam diagram nol.

\section{J. Perancangan Arsitektur Sistem}

Desain arsitektur sistem ditunjukkan pada Gambar 1 sebagai berikut:

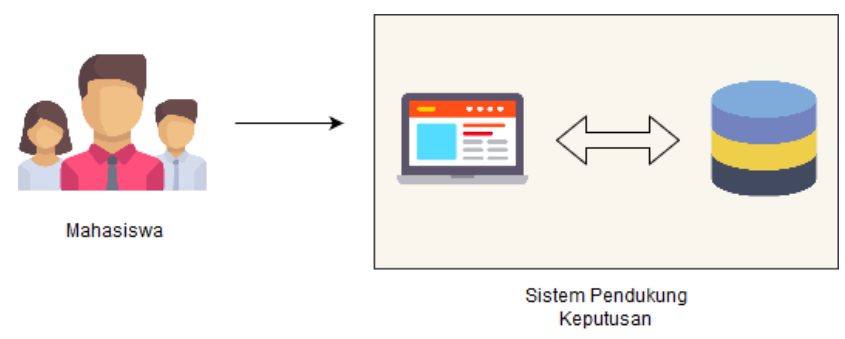

Gambar 1. Arsitektur sistem
Berdasarkan Gambar 1, mahasiswa mengakses sistem pendukung keputusan yang sudah terintegrasi dengan database. Mahasiswa mulai mengakses sistem dengan memasukkan NIM terlebih dahulu.

\section{K. Perancangan Antarmuka Sistem}

Perancangan antarmuka (interface) dirancang sebagai gambaran awal sistem yang akan dibangun. Perancangan antarmuka system meliputi beberapa pengguna diantaranya mahasiswa dan admin. Struktur antarmuka sistem dapat dilihat pada Gambar 2 sebagai berikut:

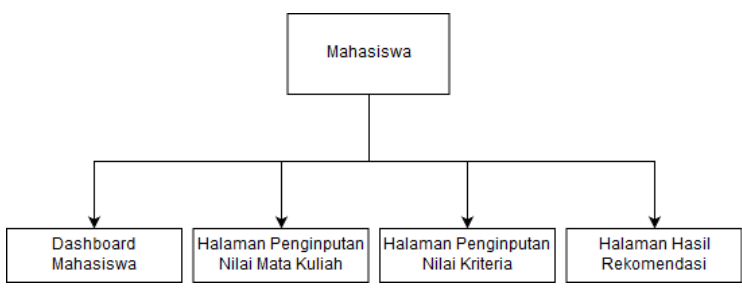

Gambar 2. Struktur Perancangan Antarmuka Sistem

Berdasarkan Gambar 2, perancangan antarmuka dibagi menjadi 4 (empat) bagian, yaitu halaman dashboard, halaman penginputan nilai mata kuliah, halaman penginputan nilai kriteria, dan halaman hasil rekomendasi.

\section{Diagram Alir Penelitian}

Metodologi penelitian merupakan suatu perencanaan penelitian yang akan dilakukan secara sistematis dan ilmiah. Metodologi penelitian tersebut diilustrasikan pada Gambar 3 berikut:

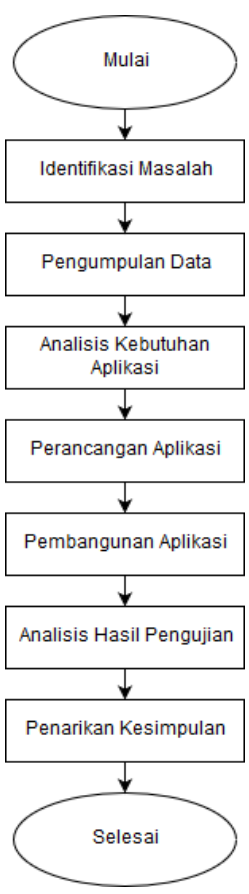

Gambar 3. Diagram alir metodologi penelitian 
Berdasarkan Gambar 3, penelitian dimulai dengan melakukan identifikasi masalah yang mana peneliti mulai menentukan solusi dari masalah yang diteliti. Kemudian dilakukan pengumpulan data berupa referensi dan data penelitian. Analisis kebutuhan dilakukan untuk menentukan variabel apa saja yang dibutuhkan dalam sistem. Perancangan aplikasi dilakukan untuk menggambarkan bagaimana sistem yang akan dibuat. Pembangunan sistem dilakukan dengan mengkodefikasi melalui bahasa pemrograman kemudian dianalisis untuk menghasilkan kesimpulan.

\section{METODOLOGI PENELITIAN}

\section{A. Hasil Perancangan}

Perancangan yang telah dilakukan terdiri dari perancangan arsitektur sistem, diagram arus data, flowchart diagram, dan perancangan basis data. Perancangan diatas menghasilkan aplkasi SPK Penentu Bidang Keahlian Mahasiswa Prodi Teknik Informatika Universitas Tanjungpura. Antarmuka yang dihasilkan adalah antarmuka awal, antarmuka input nilai kriteria, antarmuka input nilai mata kuliah, dan antarmuka hasil rekomendasi.

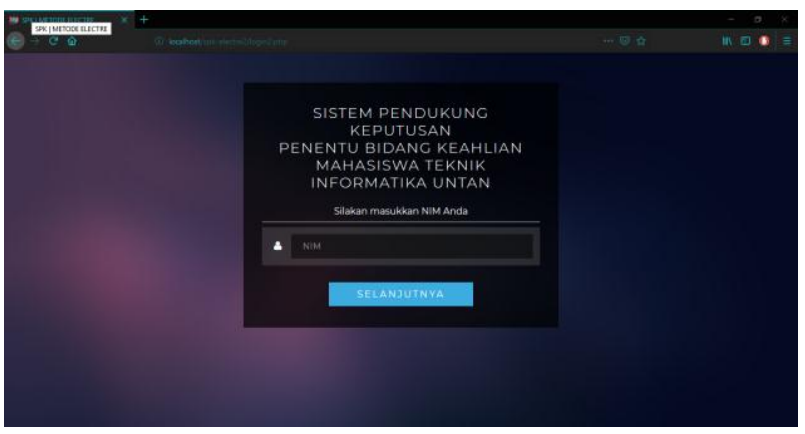

Gambar 4. Halaman awal

Berdasarkan gambar 4, mahasiswa terlebih dahulu memasukkan NIM ke form NIM agar data hasil rekomendasi ditampilkan berdasarkan NIM yang diinputkan.

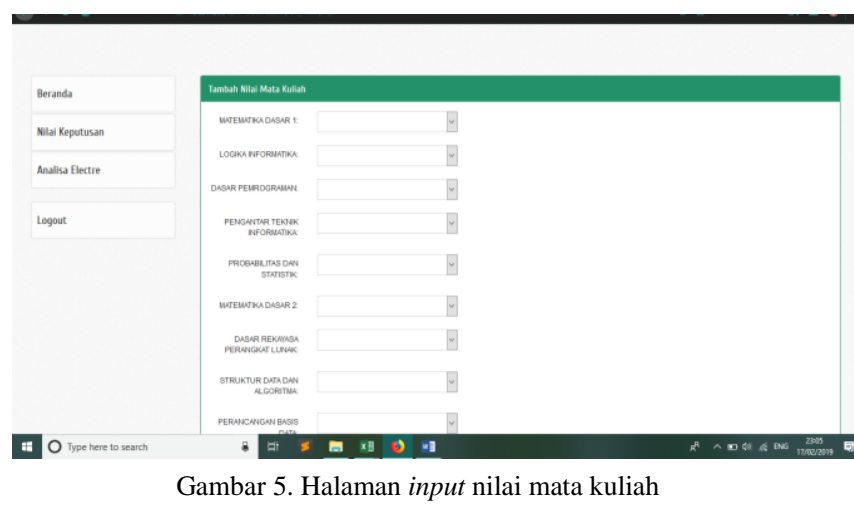

Berdasarkan gambar 5, mahasiswa menginputkan nilai mata kuliah yang tertera terlebih dahulu berdasarkan hasil pengkategorian kelompok keahlian.

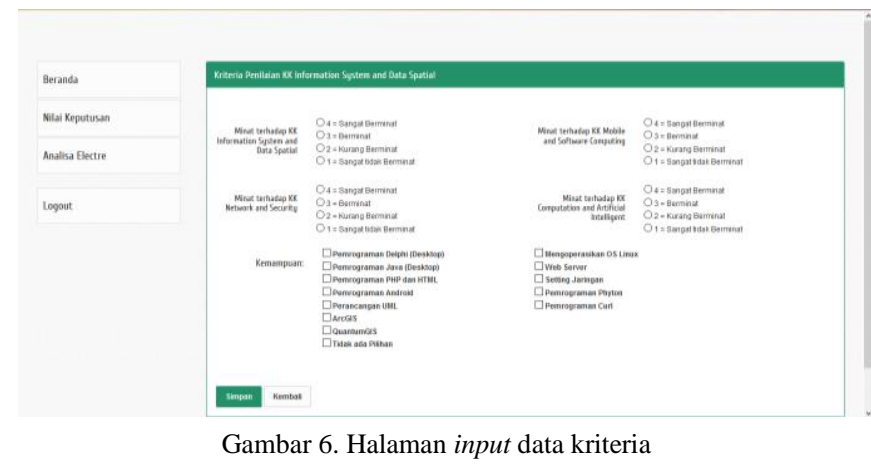

Berdasarkan gambar 6, mahasiswa menginputkan nilai kriteria berdasarkan kelompok keahlian.

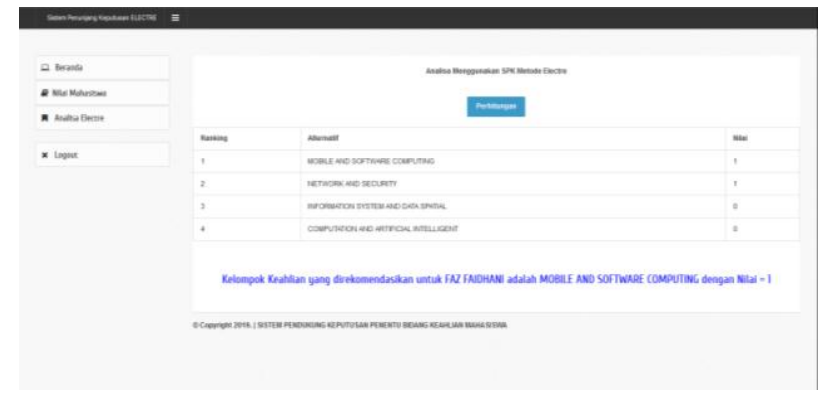

Gambar 7. Halaman Hasil Rekomendasi

Berdasarkan gambar 7, setelah semua nilai diinputkan mahasiswa akan ditujukan ke halaman hasil rekomendasi untuk melihat hasil rekomendasi bidang keahlian dari sistem.

\section{B. Hasil Pengujian}

Pengujian pada SPK Penentu Bidang Keahlian Mahasiswa Program Studi Teknik Informatika Universitas Tanjungpura dilakukan dengan 2 cara, yaitu pengujian black box untuk mengetahui hasil output sistem dan memeriksa fungsionalitas dari sistem, dan pengujian akurasi untuk menentukan kesesuaian kelompok keahlian yang dipilih mahasiswa dengan rekomendasi bidang keahlian dari sistem.

\section{Pengujian Black Box}

Pengujian ini berfokus pada fungsionalitas dari aplikasi. Pengujian ini perlu dilakukan untuk melihat output dari proses input data. Hasil pengujian memasukkan NIM ditampilkan pada Tabel 1 sebagai berikut,

TABEL 1

HASIL UJI MEMASUKKAN NIM

\begin{tabular}{|l|l|l|l|}
\hline \multicolumn{1}{|c|}{ Fungsi } & Contoh Fungsi & \multicolumn{1}{c|}{$\begin{array}{c}\text { Hasil } \\
\text { Eksekusi }\end{array}$} & Keterangan \\
\hline $\begin{array}{l}\text { Memasukkan } \\
\text { NIM }\end{array}$ & Field kosong & $\begin{array}{l}\text { Tidak } \\
\text { berhasil }\end{array}$ & $\begin{array}{l}\text { Diperintahkan } \\
\text { untuk mengisi } \\
\text { kolom yang } \\
\text { belum terisi }\end{array}$ \\
& & & \\
\cline { 2 - 4 } & Field NIM terisi & Berhasil & \\
\hline
\end{tabular}


Hasil pengujian memasukkan nilai mata kuliah ditampilkan pada Tabel 2 sebagai berikut,

TABEL II

HASIL UJI INPUT NILAI MATA KULIAH

\begin{tabular}{|c|c|c|c|}
\hline Fungsi & $\begin{array}{l}\text { Contoh } \\
\text { Fungsi }\end{array}$ & $\begin{array}{c}\text { Hasil } \\
\text { Eksekusi }\end{array}$ & Keterangan \\
\hline \multirow{3}{*}{$\begin{array}{l}\text { Fungsi } \\
\text { Input } \\
\text { Nilai } \\
\text { Mata } \\
\text { Kuliah }\end{array}$} & $\begin{array}{l}\text { Mengosongkan } \\
\text { semua kolom } \\
\text { isian }\end{array}$ & $\begin{array}{l}\text { Tidak } \\
\text { berhasil }\end{array}$ & $\begin{array}{l}\text { 'Pilih isian dari } \\
\text { daftar ini' }\end{array}$ \\
\hline & $\begin{array}{l}\text { Mengosongkan } \\
\text { salah satu } \\
\text { kolom }\end{array}$ & $\begin{array}{l}\text { Tidak } \\
\text { berhasil }\end{array}$ & $\begin{array}{l}\text { 'Pilih isian dari } \\
\text { daftar ini' }\end{array}$ \\
\hline & $\begin{array}{l}\text { Tidak ada isian } \\
\text { yang kosong }\end{array}$ & Berhasil & $\begin{array}{l}\text { 'Data behasil } \\
\text { ditambah' }\end{array}$ \\
\hline
\end{tabular}

Hasil pengujian memasukkan input data kriteria ditampilkan pada Tabel 3 sebagai berikut,

TABEL III

HASIL UJI INPUT DATA KRITERIA

\begin{tabular}{|l|l|l|l|}
\hline Fungsi & \multicolumn{1}{|c|}{$\begin{array}{c}\text { Contoh } \\
\text { Fungsi }\end{array}$} & $\begin{array}{c}\text { Hasil } \\
\text { Eksekusi }\end{array}$ & Keterangan \\
\hline \multirow{3}{*}{$\begin{array}{l}\text { Fungsi } \\
\text { Input } \\
\text { Data } \\
\text { Kriteria }\end{array}$} & $\begin{array}{l}\text { Mengosongkan } \\
\text { semua kolom } \\
\text { isian }\end{array}$ & $\begin{array}{l}\text { Tidak } \\
\text { berhasil }\end{array}$ & $\begin{array}{l}\text { 'Pilih isian dari } \\
\text { daftar ini' }\end{array}$ \\
\cline { 2 - 4 } & $\begin{array}{l}\text { Mengosongkan } \\
\text { salah satu } \\
\text { kolom }\end{array}$ & $\begin{array}{l}\text { Tidak } \\
\text { berhasil }\end{array}$ & $\begin{array}{c}\text { 'Pilih isian dari } \\
\text { daftar ini' }\end{array}$ \\
\cline { 2 - 4 } & $\begin{array}{l}\text { Tidak ada isian } \\
\text { yang kosong }\end{array}$ & Berhasil & $\begin{array}{c}\text { 'Data behasil } \\
\text { ditambah' }\end{array}$ \\
\hline
\end{tabular}

\section{Pengujian Akurasi}

Pengujian akurasi digunakan untuk melihat kesesuaian antara kelompok keahlain yang telah diambil oleh mahasiswa dengan kelompok keahlian hasil rekomendasi sistem. Hasil pengujian akurasi ditunjukkan pada Tabel 4 sebagai berikut,

TABEL IV

HASIL PENGUJIAN AKURASI

\begin{tabular}{|c|c|c|c|c|}
\hline No. & $\begin{array}{c}\text { Kelompok } \\
\text { Keahlian yang } \\
\text { Telah Diambil } \\
\text { Mahasiswa } \\
\end{array}$ & $\begin{array}{c}\text { Kelompok } \\
\text { Keahlian Hasil } \\
\text { Rekomendasi } \\
\text { Sistem } \\
\end{array}$ & Kesesuaian & Nilai \\
\hline 1 & $\begin{array}{c}\text { Computation and } \\
\text { Artificial } \\
\text { Intelligent }\end{array}$ & $\begin{array}{c}\text { Computation and } \\
\text { Artificial } \\
\text { Intelligent }\end{array}$ & Sesuai & 1 \\
\hline 2 & $\begin{array}{c}\text { Computation and } \\
\text { Artificial } \\
\text { Intelligent }\end{array}$ & $\begin{array}{c}\text { Mobile and } \\
\text { Software } \\
\text { Computing, } \\
\text { Computation and } \\
\text { Artificial } \\
\text { Intelligent }\end{array}$ & Sesuai & 1 \\
\hline 3 & $\begin{array}{c}\text { Information } \\
\text { System and Data } \\
\text { Spatial }\end{array}$ & $\begin{array}{c}\text { Network and } \\
\text { Security, } \\
\text { Computation and } \\
\text { Artificial } \\
\text { Intelligent }\end{array}$ & Tidak Sesuai & 0 \\
\hline 4 & $\begin{array}{c}\text { Information } \\
\text { System and Data } \\
\text { Spatial }\end{array}$ & $\begin{array}{l}\text { Network and } \\
\text { Security }\end{array}$ & Tidak Sesuai & 0 \\
\hline
\end{tabular}

\begin{tabular}{|c|c|c|c|c|}
\hline No. & $\begin{array}{c}\text { Kelompok } \\
\text { Keahlian yang } \\
\text { Telah Diambil } \\
\text { Mahasiswa }\end{array}$ & $\begin{array}{c}\text { Kelompok } \\
\text { Keahlian Hasil } \\
\text { Rekomendasi } \\
\text { Sistem }\end{array}$ & Kesesuaian & Nilai \\
\hline 5 & $\begin{array}{l}\text { Mobile and } \\
\text { Software } \\
\text { Computing }\end{array}$ & $\begin{array}{c}\text { Network and } \\
\text { Security, } \\
\text { Computation and } \\
\text { Artificial } \\
\text { Intelligent }\end{array}$ & Tidak Sesuai & 0 \\
\hline 6 & $\begin{array}{c}\text { Computation and } \\
\text { Artificial } \\
\text { Intelligent }\end{array}$ & $\begin{array}{l}\text { Network and } \\
\text { Security }\end{array}$ & Tidak Sesuai & 0 \\
\hline 7 & $\begin{array}{l}\text { Computation and } \\
\text { Artificial } \\
\text { Intelligent }\end{array}$ & $\begin{array}{c}\text { Tidak } \\
\text { direkomendasikan }\end{array}$ & Tidak Sesuai & 0 \\
\hline 8 & $\begin{array}{l}\text { Computation and } \\
\text { Artificial } \\
\text { Intelligent }\end{array}$ & $\begin{array}{l}\text { Computation and } \\
\text { Artificial } \\
\text { Intelligent }\end{array}$ & Sesuai & 1 \\
\hline 9 & $\begin{array}{l}\text { Computation and } \\
\text { Artificial } \\
\text { Intelligent }\end{array}$ & $\begin{array}{ll}\text { Mobile } & \text { and } \\
\text { Software } & \\
\text { Computing, } & \\
\text { Computation } & \text { and } \\
\text { Artificial } & \\
\text { Intelligent } & \\
\end{array}$ & Sesuai & 1 \\
\hline 10 & $\begin{array}{l}\text { Network and } \\
\text { Security }\end{array}$ & $\begin{array}{l}\text { Computation and } \\
\text { Artificial } \\
\text { Intelligent, Mobile } \\
\text { and Software } \\
\text { Computing }\end{array}$ & Tidak Sesuai & 0 \\
\hline \multicolumn{4}{|c|}{ Jumlah Data } & 10 \\
\hline \multicolumn{4}{|c|}{ Jumlah Data yang Sesuai } & 4 \\
\hline \multicolumn{4}{|c|}{ Persentase $(\%)$} & $40 \%$ \\
\hline
\end{tabular}

\section{Analisis Hasil Pengujian}

Analisis hasil pengujian aplikasi sistem pendukung keputusan penentu bidang keahlian mahasiswa Program Studi Informatika Universitas Tanjungpura dengan metode ELECTRE adalah sebagai berikut:

1. Hasil pengujian dengan metode black box didapat melalui percobaan input ke beberapa fungsi untuk menghasilkan output yang diiginkan. Dari beberapa percobaan tersebut disimpulkan aplikasi dapat memberikan output yang diharapkan dari input yang diberikan, sehingga dapat dikatakan aplikasi ini berhasil melalui pengujian black box.

2. Hasil pengujian akurasi pada 10 (sepuluh) mahasiswa memberikan hasil akurasi dengan kesesuaian rekomendasi sistem dengan kelompok keahlian sebesar $40 \%$ yang mana 4 (empat) mahasiswa kelompok keahlian yang dipilih sesuai dan 6 (enam) mahasiswa tidak memiliki kesesuaian. Berdasarkan hasil wawancara mengenai faktor pemilihan judul skripsi, ada 7 (tujuh) mahasiswa memilih judul skripsi berdasarkan minat dan 4 (empat) mahasiswa memilih judul skripsi karena saran dosen.

\section{KESIMPULAN}

Kesimpulan yang didapat dari hasil metodologi penelitian, analisis sistem, pengujian, dan perancangan terhadap sistem pendukung keputusan penentu bidang keahlian mahasiswa adalah sebagai berikut: 
1. Sistem pendukung keputusan penentu bidang keahlian mahasiswa Program Studi Informatika Universitas Tanjungpura dengan Metode ELECTRE dapat menghasilkan rekomendasi bidang keahlian bagi mahasiswa dengan perankingan yang mana hasil yang tertinggi adalah bidang keahlian yang direkomendasikan.

2. Berdasarkan hasil pengujian terhadap 10 (sepuluh) mahasiswa, metode Elimination Choice and Translating Reality (ELECTRE) memiliki nilai akurasi sebesar $40 \%$ terhadap rekomendasi bidang keahlian mahasiswa Program Studi Informatika Universitas Tanjungpura.

3. Kriteria minat menjadi kriteria yang berpengaruh dalam menentukan bidang keahlian mahasiswa Program Studi Informatika Universitas Tanjungpura.

\section{REFERENSI}

[1] Yumarlin MZ. 2016. Sistem Pendukung Keputusan Konsentrasi dan Peminatan Prodi Teknik Informatika Universitas Janabadra Yogyakarta. Citec Journal, Vol. 3, No. 4, Agustus 2016 - Oktober 2016

[2] Pradana, Musthofa Galih. 2017. Sistem Pendukung Keputusan Pemilihan Konsentrasi Mahasiswa Informatika Universitas AMIKOM Yogyakarta Menggunakan Algoritma SAW Berbasis Website. Universitas AMIKOM Yogyakarta.

[3] Rahmayu, Mulia dan Rosi Kusuma Serli. 2018. Sistem Pendukung Keputusan Pemilihan Jurusan Pada SMK Putra Nusantara Jakarta Menggunakan Metode Analytical Hierarchy Process (AHP). Jurnal SIMETRIS, Vol 9 No. 1 April 2018.

[4] Teknik Informatika Universitas Tanjungpura. 2016. Tentang Prodi. Informatika.untan.ac.id/?single\&id=135, diakses pada Juli 2018.

[5] Daihani, Dadan Umar. 2001. Komputerisasi Pengambilan Keputusan. Jakarta : PT. Elex Media Komputindo.

[6] Turban, E. 2005. Decision Support Systems and Intellignet Systems (Edisi 7 Jilid 1).Yogyakarta : Penerbit Andi.

[7] Haryanti, Dwi. 2016. Sistem Pendukung Keputusan Seleksi PenerimaanMahasiswa Pengganti Beasiswa Penuh Bidikmisi Universitas Tanjungpura Dengan Menerapkan Metode SMARTER. Jurnal Sistem dan Teknologi Informasi (JUSTIN) Vol. 1, No. 1, 2016.

[8] Suparmaji. 2017. Sistem Rental Mobil Di Kota Bengkulu Dengan Metode ELECTRE IV Dalam Membuat Keputusan Pemilihan Mobil Rental Berbasis Website. Jurnal Rekursif Vol. 5 No, 3 November 2017 Universitas Bengkulu.

[9] Akhirina, Tri Yani. 2016. Komparasi Metode Simple Additive Weighting dan Profile Matching pada Pemilihan Mitra Jasa Pengiriman Barang. Jurnal Edukasi dan Penelitian Informatika (JEPIN) Vol. 2, No. 1, (Juni 2016).

[10] Jati, Antonius Prabowo. 2017. Rancang Bangun Alat Bantu Sistem Pendukung Pengambilan Keputusan Dengan Metode ELECTRE. Universitas Sanata Dharma Yogyakarta.

[11] Kusumadewi, Sri. 2006. Fuzzy Multi-Attribute Decision Making. Yogyakarta : Graha Ilmu.

[12] Setiawan, Fahmi. 2015. Implementasi Metode Electre Pada Sistem Pendukung Keputusan SNMPTN Jalur Undangan. Kumpulan JurnaL Ilmu Komputer (KLIK) Volume 02, No.02 September 2015.

[13] Arief, M. Rudianto. 2011. Pemrograman Web Dinamis Menggunakan PHP dan MySQL. Yogyakarta: Andi Offset.

[14] Pressman, Roger S. 2012. Rekayasa Perangkat Lunak (Pendekatan Praktisi) Edisi 7 : Buku 1. Yogyakarta : Penerbit Andi.

[15] Sukamto, Rosa Ariani dan Muhammad Shalahuddin. 2013. Rekayasa Perangkat Lunak Terstruktur dan Berorientasi Objek. Bandung : Penerbit Informatika.

[16] Susanto, Azhar. 2008. Sistem Informasi Akuntansi. Jakarta: Gramedia.

[17] Kristanto, Andri. 2004. Rekayasa Perangkat Lunak (Konsep Dasar). Yogyakarta : Penerbit Gava Media.

[18] Indrajani. 2011. Perancangan Basis Data Dalam All in 1. Jakarta : PT. Elex Media Komputindo.
[19] Jogiyanto. 2005. Analisis dan Desain Sistem Informasi : Pendekatan Terstuktur Teori dan Praktek Aplikasi Bisnis. Yogyakarta : Penerbit Andi. 